\title{
Identifying Business Models for Re-use of Cultural Objects by Using Modern ICT Tools
}

\author{
Cristian CIUREA ${ }^{1}$, Florin Gheorghe FILIP ${ }^{2}$ \\ ${ }^{1}$ Bucharest University of Economic Studies, Bucharest, Romania \\ ${ }^{2}$ Romanian Academy - INCE \& BAR, Bucharest, Romania \\ cristian.ciurea@ie.ase.ro, ffilip@acad.ro
}

In this paper is presented an economic model for revitalization of cultural institutions with the help of modern information and communication technologies tools and techniques. By revitalization of cultural institutions we mean the increase in terms of public image, visibility, number of visitors, and not lately, revenues. One of the modern ICT techniques used in this situation is the implementation of virtual exhibitions for promotion and valorization of cultural collections and cultural heritage elements. There are already available excellent ICT tools (one example to be described in the paper is MOVIO) that are used to create virtual exhibitions, some of them being implemented within cultural European projects.

Keywords: Business Model, Cultural Heritage, Digitization, Revitalization, Virtual Exhibitions.

1 Introduction

The objective of this paper is to show that cultural institutions, especially libraries and museums, are not only knowledge depositaries through the preservation of cultural heritage, but are also knowledge creators with the help of modern information and communication technologies. In the last years, a new concept appeared in cultural heritage area, namely the virtual exhibitions. Many scientific publications have presented this concept and its advantages, some of them written by the authors of this paper. There are available many scientific articles and books that have been published over the last years, especially on the topic of exploitation and promotion of existing cultural heritage collections from European museums and libraries [1], [2].

As defined in [3], a virtual exhibition transposes the essence of cultural objects presented in physical format into the digital world and makes this essence available to visitors from any place and at any time, in a effectively and efficiently manner.

The idea is that virtual exhibitions have radically changed the vision of cultural institutions managers about the digitization and preservation of cultural heritage collections, because they have realized that keeping a cultural object locked in a deposit room and make it available to a few number of visitors in the original format is not a better solution for the long-term preservation. At the same time, this is not a better solution to increase the number of visitors and for the long-term development of cultural institution. Managers of libraries and museums have accepted that is not a good idea to make available to the public the cultural item in the physical way and is a very good idea to digitize the cultural objects and make them available online to the public, in a free or freemium manner [4].

There are some key points that must be highlighted regarding the digitization of cultural heritage collections. At this time, only $10 \%$ of overall collections from European cultural institutions have been digitized. The remaining $90 \%$ should be digitized in the next few years, in a rapid manner, because Europe has realized that the cultural heritage can be exploited as a strategic economic resource [5]. Considering the current economic situation in Europe and the future strategies, cultural institutions should not depend too much from public budget financing, and should try to become autonomous from this point of view. The virtual exhibitions not only provide a better way to make known the unique collections of books, old and rare manuscripts, paintings, sculptures and other cultural objects 
preserved by cultural institutions, but offers also some advantages to cultural institutions, such as the increase of visitors number, public image visibility, growth of revenues based on entrance fees applied to visitors and so on.

The virtual exhibitions represents a new research field that needs to be exploited, because it has less theoretical background to show its research potential and development direction. The development of a modeling framework for virtual exhibitions is very important for IT managers and designers in this field [6].

Excepting the main objective of a virtual exhibition, which consists in promotion and valorization of cultural heritage collections, a secondary objective means to allow the visitors to experience alternative routes for exploration and navigation through the cultural content. In this way, the visitors can achieve possibilities that they were not able to find in a physical exhibition [7].

\section{Proposed Business Model for Revitalization of Cultural Institutions}

One of keywords from the paper title is "revitalization" of cultural institutions. We have chosen this word because many cultural institutions needs a helping hand to adapt at the current technological revolution, to take advantage of facilities offered by modern information and communication technologies. Not only the ICT tools and techniques are applied in cultural sector for revitalization, but also some marketing strategies. Virtual exhibitions imply elements from many fields, including ICT, and marketing. The implementation of a virtual exhibition means not only to post some images about cultural objects in a picture gallery, but also to make the whole product to be attractive for visitors. Cultural institutions represents non-profit organizations that does not intend to obtain profit and which have the objective to preserve public goods, such as cultural heritage collections [13]. In the last years, significant investments have been made in the digitization of cultural heritage objects inside cultural institutions. The physical collections became new digital collections that have emerged and offered innovative solutions to explore its objects, especially with the support of modern information and communication technologies.

Business models represents the way in which the value is created, delivered and captured from an organization point of view [14]. In the case of public cultural institutions, business models need to be seen in a wider sense if they are implemented to create revenues.

We have developed a business model for revitalization of cultural institutions with the help of virtual exhibitions. It extends the initial idea described in [8]. A simplified diagram of this model is presented in Figure 1. The proposed business model is intended to represent a starting point in the development of other business models that will be applied in real cultural institutions.

As presented in [9], in the light of the economic uncertainties at European level, the development of new business models for the creative re-use of digital cultural content must allow wider access to cultural heritage collections on the one hand and, on the other hand, these business models needs to create revenues to guarantee the long-term sustainability of cultural institutions. 


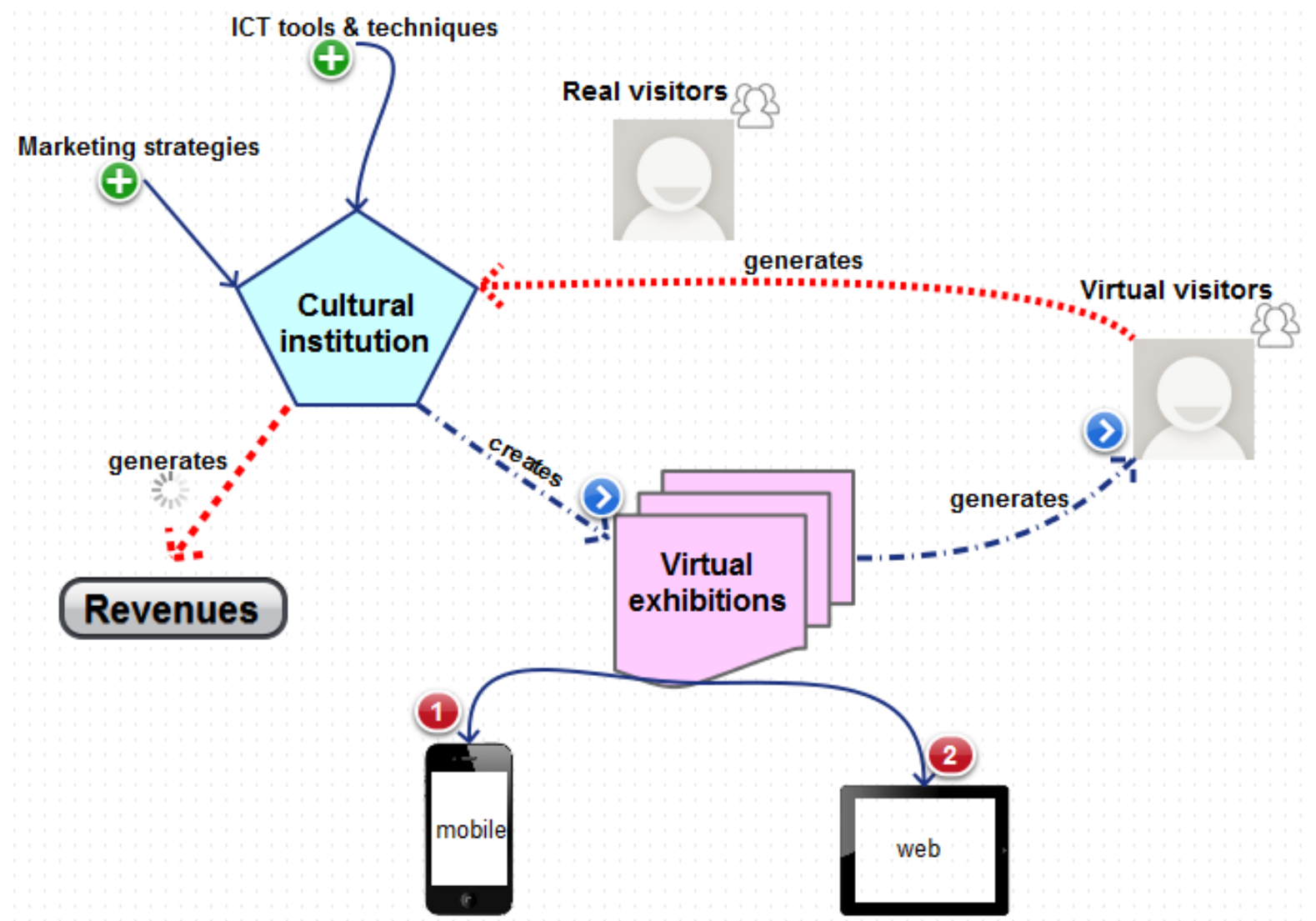

Fig. 1. Business model diagram

The diagram of Figure 1 describes the business model proposed. By applying marketing strategies and ICT tools and techniques to cultural institutions, they will create attractive virtual exhibitions, which will present the most beautiful digitized copies of cultural objects. Virtual exhibitions can be developed as native mobile applications that will be installed on mobile devices with operating systems, such as Android, iOS, Windows Phone and so on, or as web applications, which will be accessed online from any PC connected to Internet. The virtual exhibitions will "generate" virtual visitors that are interested to find more about the exhibits presented in the application and a part of them will become real visitors of cultural institutions. In that case, virtual exhibitions may be viewed as a visit card or a catalogue that can offer the cultural institution to real visitors. The real visitors that were attracted to discover more about the exhibits presented in the virtual exhibition are influenced to visit the cultural institution and, consequently, will be willing to pay entrance fees or some special fees to get copies or personalized objects with the cultural objects. For example, Rijksmuseum in Amsterdam offers personalized t-shirts or cups with images of known painters from their collections. The output of this business model means an increase of revenues of cultural institutions and also an increase of public image and number of visitors [9].

Taking into consideration the economic uncertainties in Europe and the decrease of governmental budgets, ensuring the sustainability is the main concern and challenge. As a solution, the development and implementation of new business models in cultural institutions for the re-use of digital content seems to be "double-edged" [13]. In the first way, the business models should allow wider access to cultural collections, while guaranteeing the copyrights and intellectual property rights. In the second way, they also need to create revenues to guarantee the long-term sustainability of third parties which are exploiting the digital content. 
In order to achieve sustainability in cultural sector it should realize a change in management on the side of cultural heritage institutions. These organizations must establish clear goals, measurable targets, review processes and assess their performance. The elements mentioned previously are proven elements in the business sector in order to create successful companies, but are considered weaknesses for cultural heritage institutions [15].

\section{Costs of Virtual Exhibitions Implementation}

When a cultural institution decides to implement a new virtual exhibition, it must take into account the implementation costs generated by employment of ICT specialists or acquisition of specific tools and software licenses. These costs should be supported by the cultural institution or by different sponsorships offered by private companies or NGOs (non governmental organizations). When the proposed business model is achieved, these costs will be covered by the entrance and other fees collected from new visitors.

Depending on the available budget for the development of virtual exhibition, the cultural institution can decide which type of implementation to select. In the case of virtual exhibitions implemented as native mobile applications, if the cultural institution wants to develop the mobile application for all operating platforms (Android, iOS, Windows Phone), then the costs will be higher. If the exhibition is developed only for a specific mobile operating system, then the target public will be limited to the users that have mobile devices with the specific operating system. The users of the other mobile operating system can feel frustrated because they do not have access to the application. So, the solution is to create an application that can be accessed from any device. The virtual exhibition can be implemented as a crossplatform solution that can be accessed from any mobile device and from any computer. It is a web application with responsive interface. There are many interesting technologies that allow the development of this kind of applications (for example, SAP UI5) [10].

Regardless the type of implementation, the costs can be different depending on many other influence factors, including salaries of specialists, digitization level of cultural objects selected to be presented, or other administrative costs. More aspects about building mobile applications for virtual exhibitions and other information systems can be found in [5] and [11].

In the last few years, we have implemented at the Romanian Academy Library the following virtual exhibitions, using a dedicated tool named MOVIO [12]:

- Constantin Brancoveanu - prince of Wallachia, available at: http://movio.biblacad.ro/BRANCO/

- Greek Coins - Constantin Orghidan collection of the Romanian Academy Library, available at: http://movio.biblacad.ro/COINS/

- Seals - the history treasure, available at: http://movio.biblacad.ro/SEALS/

- Stefan Luchian - illustrator, available at: http://movio.biblacad.ro/LUCHIAN/

- Saint Antim Ivireanul, available at: http://movio.biblacad.ro/ANTIM/

- To other worlds - painting exhibition of Vasilica CHIFU, available at: http://movio.biblacad.ro/CHIFU/

- Interferences - Painting exhibition by Marius CRISTEA, available at: http://movio.biblacad.ro/CRISTEA/

- Church of the Argeş Monastery - Half a millennium (1517 - 2017), available at: http://movio.biblacad.ro/curteadearges/

- King Ferdinand I, available at: http://movio.biblacad.ro/FERDINAND/

In the Figure 2 below is presented a mixture between screen captures of the previous six virtual exhibitions, accessed as mobile applications. 


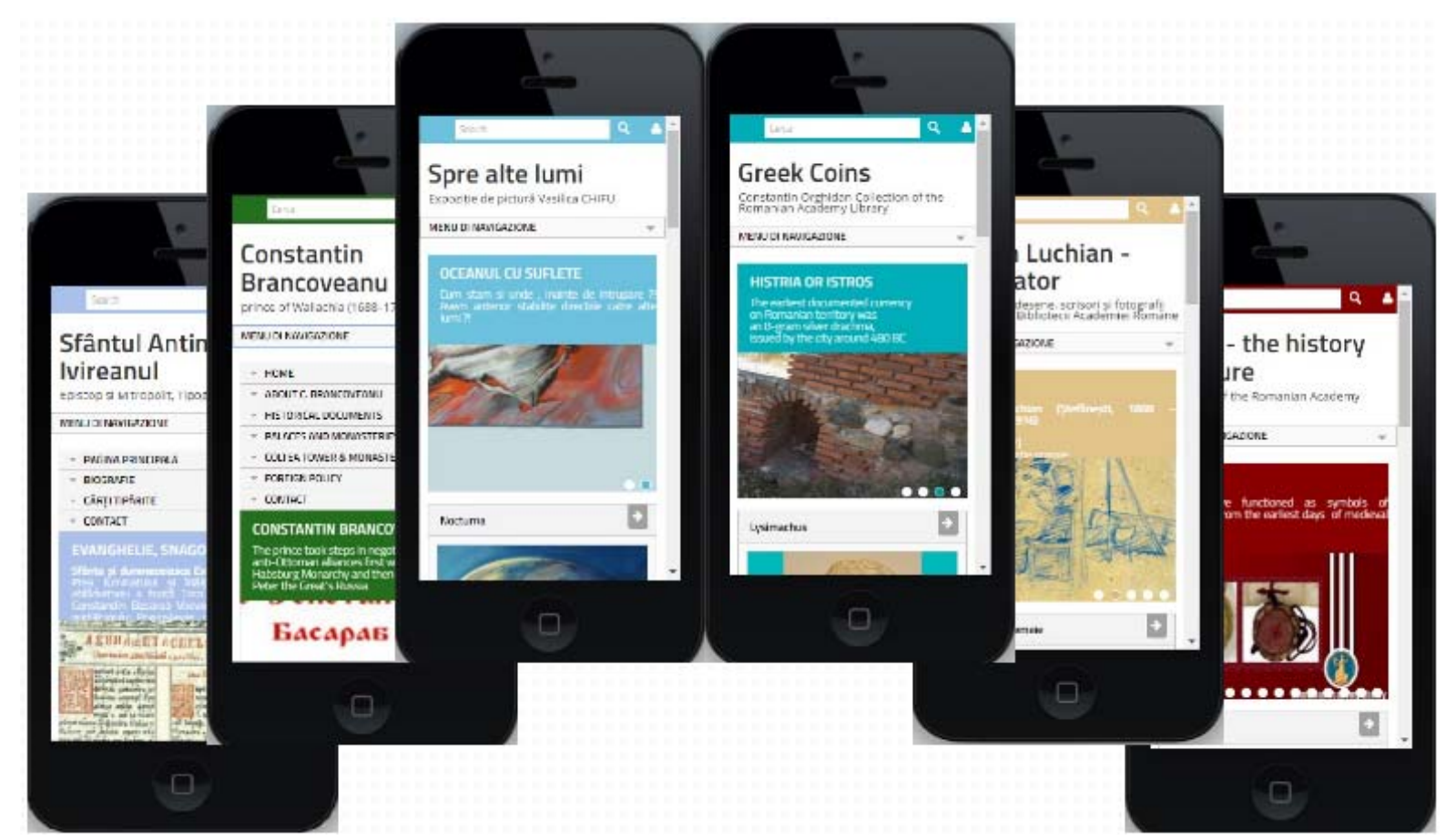

Fig. 2. Collage of virtual exhibitions in mobile view

All of these virtual exhibitions are only the beginning of what can be done with the involvement of ICT specialists and usage of dedicated tools and techniques for development of amazing software products and applications in cultural sector.
The Figure 3 below shows the timeline functionality offered by the MOVIO tool, in order to display to the user the cultural objects on a historical map, creating relationships between objects based on their time and date.

\section{Marea Adunare Naţională de la Alba lulia de la 1 Decembrie 1918}
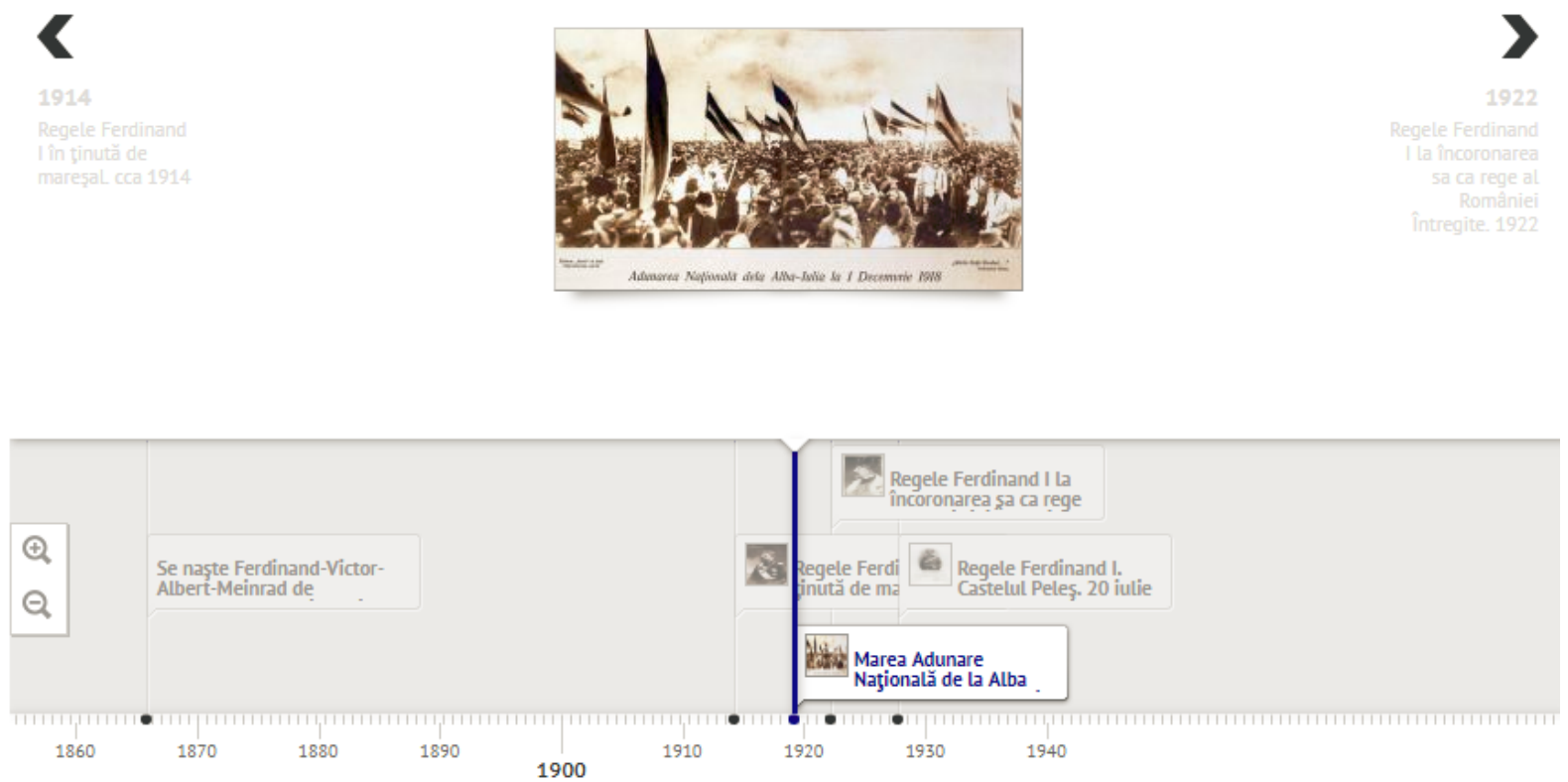

Fig. 3. Timeline in a virtual exhibition 
The business models which are developed for applications that re-use cultural resources should fulfill the followings requirements [16]:

- open access and open source;

- revenues from (in)direct beneficiaries;

- provide additional services and goods.

There are the followings business model taxonomies that can be applied in cultural heritage institutions [16]:

- Service Based Business Model: it suppose that companies sell specific services around a product rather than selling the product itself or to create customized versions of the product for other sectors (educational sector);

- White Labelling: it is used in the trading services sector, where a third party uses a service through a provider by rebranding the product;

- Advertising Revenue Model: inserting advertisement on a website is a traditional solution, but also a very applicable revenue model;

- Corporate Sponsorships: is the case when a sponsor is providing financially support or through products and services;

- The Freemium Model: allows users to obtain a free access to a service or product and offers additionally features or services against payment;

- Donation-Based Crowdfunding Model: means to receive resources from a community of users, which gets no monetary return of investment; instead the product or service can be used for free.

\section{Conclusions}

The main finding of our research is that modern information and communication technologies can contribute to the development of many human activity fields, including the cultural sector. The central idea of the business model proposed in this paper is that specialists in computer science will bring modern information and communication technologies in cultural institutions and this will contribute at the cultural institutions progress, both culturally and economically.
The current technological revolution that we are experiencing has radically changed many aspects of existing human activity domains, some of them disappeared and others were reinvented. In a future research we will analyze in depth how ICT tools and techniques have impacted the cultural institutions.

\section{Acknowledgment}

Parts of this research have been published in the Proceedings of the $16^{\text {th }}$ International Conference on Informatics in Economy, IE 2017

\section{References}

[1] S. Styliani, L. Fotis, K. Kostas, P. Petros, "Virtual museums, a survey and some issues for consideration", Journal of Cultural Heritage, No. 10, 2009, pp. 520528.

[2] V. Dziekan, Virtuality and the Art of Exhibition. Curatorial Design for the Multimedia Museum, Chicago, IL: The University of Chicago Press, 2012.

[3] L. Corovic, V. Vuksan, A. Sofronijevic, "Virtual exhibition as a medium for presenting scientific and cultural heritage to international audiences: Dorde Stanojevic - a rector who lit up Belgrade", The 9th SEEDI Conference: Digitisation of cultural and scientific heritage, Belgrade, Serbia, 15th - 16th May, 2014.

[4] F. G. Filip, C. Ciurea, H. Dragomirescu, I. Ivan, "Cultural Heritage and Modern Information and Communication Technologies," Technological and Economic Development of Economy, 21(3), May 2015, Taylor \& Francis, pp. 441-459.

[5] C. Ciurea, F. G. Filip, "New Researches on the Role of Virtual Exhibitions in Digitization, Preservation and Valorization of Cultural Heritage," Informatica Economică, Vol. 20, No. 4, 2016, pp. 2633.

[6] H. Ling, D. Dai, “A Modeling Framework for Virtual Exhibition," 2010 International Conference on Management and Service Science, Wuhan, 2010, pp. 1-5. 
[7] G. Lepouras, A. Katifori, C. Vassilakis, D. Charitos, "Real Exhibitions in a Virtual Museum”, Virtual Reality, Vol. 7, No. 2, 2004, pp. 120-128.

[8] F. G. Filip, D. A. Donciulescu, C. I. Filip, "A cybernetic model of computerization of the cultural heritage," Computer Science Journal of Moldova, Vol. 9, No. 2 (26), 2001, pp. 101-112, Available at: http://www.math.md/files/csjm/v9-n2/v9n2-(pp101-112).pdf

[9] N. Kreinberger, F. Thinnes, N. Timmermans, "Identifying business models for the re-use of cultural objects for tourism," Europeana Creative - White Paper: Business Models for Tourism, 2014, Available at: http://pro.europeana.eu/files/Europeana_P rofessional/Projects/Project_list/European a_Creative/WP3\%20\%20Business\%20Model\%20Frameworks/ eCreative_WP3_White_Paper_Business Models Tourism v1.0.pdf

[10] Q. S. Wang; C. A. O. Lin, Packaging and deploying hybrid applications. U.S. Patent Application No 14/032,184, 2013.

[11] F. G. Filip, "A decision-making perspective for designing and building information systems," International Journal of Computers Communications \& Control, Vol. 7, No. 2, 2014, pp. 264-272.

[12] M. T. Natale, S. H. Minelli, B. Dierickx, P. Ongaro, M. Piccininno, D. Ugoletti, A. Raggioli, "Exhibiting Intangible Cultural Heritage using MOVIO: a multilingual toolkit for creating curated digital exhibitions," ICOM 2014-Access and
Understanding-Networking in the Digital Era: intangible Cultural Heritage, 2014.

[13] C. Feijoo, S. Lindmark, J. P. Villar, C. Tarín, J. Gelabert, B. Matía, "Public and Commercial Models of Access in the Digital Era", Directorate-General for Internal Policies, April 2013, requested by the European Parliament's Committee on Culture and Education; Available at: http://www.europarl.europa.eu/RegData/et udes/etudes/join/2013/495858/IPOLCUL T ET(2013)495858 EN.pdf, p. 119.

[14] Strategyzer, 2014, Available at: http://www.businessmodelgeneration.com

[15] A. Escande, H. de Haan, L. Edwards, Europeana Creative White Paper No. 1. Creativity, Technology and Management: Establishing Best Practices between Cultural Heritage Institutions and the Creative Industries, June 2013, Available at:

http://pro.europeana.eu/documents/15389 74/1594727/eCreative_WP3_ST3.2.1_Cre ativityTechnologyManagement_v1.0.

[16] N. Kreinberger, F. Thinnes, N. Timmermans, White Paper: Business Models for Tourism - Identifying business models for the re-use of cultural objects for tourism, July 2014, Available at: https://pro.europeana.eu/files/Europeana_ Professional/Projects/Project_list/Europea na Creative/WP3\%20$\% \overline{2}$ BBusiness \%20Model\%20Frameworks/ eCreative_WP3_White_Paper_Business Models_Tourism_v1.0.pdf

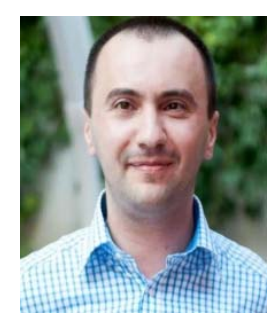

Cristian CIUREA is Associate Professor at the Department of Economic Informatics and Cybernetics from Bucharest University of Economic Studies. $\mathrm{He}$ has graduated the Faculty of Economic Cybernetics, Statistics and Informatics from the Bucharest University of Economic Studies in 2007. He has a master in Informatics Project Management (2010) and a $\mathrm{PhD}$ in Economic Informatics (2011) from the Bucharest University of Economic Studies. Cristian has a solid background in computer science and is interested in collaborative systems related issues. Other fields of interest include software metrics, data structures, object oriented programming, windows applications programming, mobile devices programming and testing process automation for software quality assurance. 


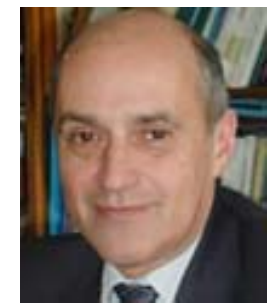

Florin Gheorghe FILIP took his MSc and $\mathrm{PhD}$ in control engineering from the TU "Politehnica" of Bucharest. In $1991 \mathrm{He}$ was elected as a member of the Romanian Academy (RA). He has been a scientific researcher at the National R\&D Institute in Informatics (ICI) of Bucharest. Currently he is a part-time researcher at the National Institute of Economic Researches (INCE) of the RA, also the director of the Library of the Academy. He was elected as vicepresident of RA in 2000 and reelected in 2002 and 2006. His main scientific interests include large-scale systems, decision support systems, technology management and foresight. 